from Elkin's new computed values of Bessel's measures made with the Konigsberg heliometer. The following table is of interest, as it brings out the great accuracy of the Göttingen observations, and leads to suggestions regarding the grouping of the stars in numerous systems.

\begin{tabular}{|c|c|c|c|c|}
\hline \multirow{2}{*}{ Stars. } & \multicolumn{2}{|c|}{ Göttingen. -Königsberg. } & \multicolumn{2}{|c|}{$\begin{array}{l}\text { Relative proper motion for } 50 \\
\text { years in }\end{array}$} \\
\hline & R.A. & Decl. & Magnitude. & Direction. \\
\hline$g$ & to 06 & +0.09 & 0.13 & $29^{\circ} \circ$ \\
\hline$b$ & +0.20 & 10.42 & 0.46 & $23 \cdot 2$ \\
\hline$m$ & -0.66 & -0.18 & 0.63 & $253 \cdot 3$ \\
\hline$e$ & +0.49 & +0.12 & 0.47 & $75^{\prime} \cdot$ \\
\hline$c$ & +0.52 & +0.07 & 049 & $8 I \cdot I$ \\
\hline$k$ & +001 & +0.13 & 0.14 & $4^{\circ} 4$ \\
\hline$l$ & +0.09 & +0.16 & 0.18 & $26 \cdot 6$ \\
\hline$d$ & -0.35 & -0.06 & 0.33 & $259^{\circ} 5$ \\
\hline 12 & -0.60 & -0.01 & 0.55 & 268.9 \\
\hline$\eta$ & - & 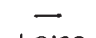 & - & $\bar{c}$ \\
\hline 28 & +0.12 & +0.22 & 0.25 & 266 \\
\hline$s$ & +130 & -0.76 & I 42 & 1225 \\
\hline$f$ & -0.04 & -0.16 & 0.17 & $194^{\circ} \mathrm{I}$ \\
\hline$h$ & $\div 0.04$ & +0.03 & 0.05 & $53^{\circ} \cdot 1$ \\
\hline 34 & +0.60 & +0.23 & 0.60 & 673 \\
\hline 40 & +0.44 & +0.50 & 0.64 & 38.7 \\
\hline
\end{tabular}

Dr. Ambronn points out that the proper motions appear to show, just as those of Elkin's indicated, that the stars form not one but several systems. As will be seen from the table, $g, b$, $k, l$ (and 28) appear to group themselves together, so also $c$ with $c$, and the three stars $m, d, 12$, with one another. For a more definite opinion on this point it is suggested that the number of stars observed must be greatly increased.

The result of the triangulation shows, however, that by a suitable determination of the instrumental constants and due care in arranging the measures for reduction, small heliometers can give results, especially with regard to distances, which compare very favourably with instruments of much larger
size.

The Fiftil Satellite of Jupiter. - A series of micrometrical measures of the fifth satellite of Jupiter, made during the opposition of the planet in 1893, is contributed to the Astrontomical Fournal, No. 325, by Prof. E. E. Barnard. From numerous observations, Prof. Barnard is confident that the satellite is not brighter than the thirteenth magnitude. Its sidereal period appears to he I I h. $57 \mathrm{~m}$. $22 \cdot 618 \mathrm{~s}$. Filarmicrometer measures of the diameters of Jupiter were made in the course of the work, the following values being obtained:-

Equatorial diameter $\quad \ldots \quad \ldots \quad 90,190 \pm 56$ miles.

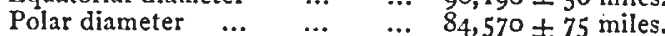

The polar compression oblained from these measures is $1 / 15.98$. The mean of measures of east elongations of the satellite, made from September 1893 to January IS94, correspond to a dis. tance of III,9I0 miles. But on account of the eccentricity and revolution of the orbit of the satellite, the elongation distance is a varying quantity. M. Tisserand was led to conclude, a short. time ago, that the major axis of the satellite's orbit must make a complete revolution in about five months. He returns to the subject in Comples-renduts for October 8, having used Prof. Barnard's new measures to make another determination of the eccentricity and the longitude of perijove at a given epoch. His discussion of the observations has led to the following results :-Semi-major axis, 47".906; eccentricity, 0.0073; longitude of perijove at the epoch October $28,1892,-14^{\circ}$.

\section{THE PAST SUMMER.}

$A N$ examination of the meteorological results for the six months from April to September exhibit some features of interest by way of showing how the several elements of temperature, rainfall, and sunshine combine to make up what is commonly called weather, and how, as in the case of the summer in question, the absence of sunshine can mar the No. I 304 , VOL. 50] season. In some summers the character of the weather varies considerably in different parts of the kingdom, but during the recent summer there was a great similarity in the conditions over the whole of the British Islands, and consequently the principal facts in the following summary, deduced from observations in the neighbourhood of London, will, to a great extent, be an index for other parts of the kingdom.

Table showing the Temperatures at Greenwich for the several Months and for the whole Summer.

\begin{tabular}{|c|c|c|c|c|c|c|c|c|}
\hline & 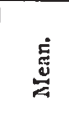 & 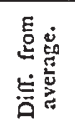 & 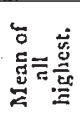 & 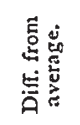 & 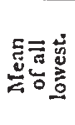 & 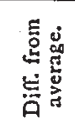 & 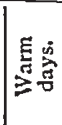 & 궁ำ \\
\hline $\begin{array}{c}\text { April ... } \\
\text { Mlay ... } \\
\text { Jure ... } \\
\text { July ... } \\
\text { August.. } \\
\text { Sept. ... }\end{array}$ & $\begin{array}{l}51 \cdot 9 \\
51 \cdot 8 \\
59 \cdot 8 \\
63 \cdot 6 \\
61 \cdot 4 \\
55^{\circ} \cdot 2\end{array}$ & $\begin{array}{r}+3.8 \\
+3.1 \\
-2.6 \\
-0.0 \\
-1.5 \\
-3.0\end{array}$ & $\begin{array}{l}6 i \cdot 8 \\
61 \cdot 1 \\
69 \cdot 2 \\
73 \cdot 0 \\
69 \cdot 2 \\
62 \cdot 2\end{array}$ & $\begin{array}{l}0 \\
+4.6 \\
-3 \cdot 1 \\
-1.7 \\
-1.0 \\
-3.6 \\
-5 \cdot 1\end{array}$ & $\begin{array}{l}410 \\
42 \cdot 5 \\
50 \cdot 4 \\
54 \cdot 1 \\
53 \cdot 6 \\
48 \cdot 1\end{array}$ & $\begin{array}{l}+0 \\
+3 \cdot 0 \\
-1 \cdot 2 \\
+0.5 \\
+1 \cdot 0 \\
+0.6 \\
-1.0\end{array}$ & $\begin{array}{r}26 \\
10 \\
11 \\
13 \\
5 \\
6\end{array}$ & $\begin{array}{r}4 \\
21 \\
19 \\
18 \\
26 \\
24\end{array}$ \\
\hline um: & $57 \cdot 3$ & -0.6 & $66 \cdot 1$ & $-1 \cdot 6$ & $48 \cdot 4$ & +0.4 & 71 & 112 \\
\hline
\end{tabular}

The averages used in the above comparison are for the 50 years 184 I to 1890 . A warm day is one on which the mean daily temperature is above the average, and a cold day is one on which the mean daily temperature is below the average.

It will be noticed that the mean maximum temperature is below the average, except in April; while the mean minimum temperature is in excess of the average, except in May and September. The highest day temperatures at Greenwich only reached $70^{\circ}$ or above on 51 days, and they were distributed as fol. lows throughout the summer :-A pril, 3 days; May, 2 ; June, 12 . July, 21 ; August, 12; and September, 1 . There were in all only 7 days with a temperature of $80^{\circ}$ or above; they occurred as foliows :-June, 3; July, 3; and August $\mathbf{r}$. For the last 50 years, $1845 \cdot 1894$, there have been on the average 75 day's with a tem. perature of $70^{\circ}$ and above, and 15 days with a temperature of $80^{\circ}$ and above. The summers of 1860,1879 , and 1888 each had a fewer number of hot days than the summer which has just passed, while $1846,1857,1858,1865,1868$, and 1893 each had double the number of hot days. Last year the mean tempera. ture for the whole summer was more than $3^{\circ}$ in excess of the mean for the summer this year, but the summer last year was warmer than any during the last half-century, although it was only $0^{\circ} \cdot 2$ warmer than in 1868 .

The following table gives the rainfall and sunshine at Green. wich, and the sunshine values at Westminster, for the several months and for the whole summer :-

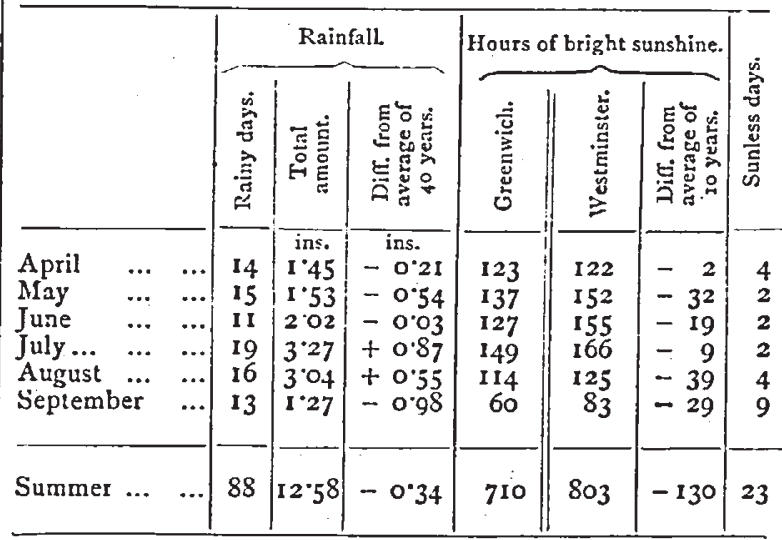

The above figures show that rain fell with great frequency, but the amount was by no means excessive, and, with the exception of July and August, the monthly falls were below the average. A slightly different result is obtained if the comparison is made with the last 50 years, 1845 to 1894 , the average total fall in summer for that period being 12.66 inches, which gives a deficiency of 0.08 inch only for the recent 
summer. During the whole period of 50 years, the summer falls have been deficient in $\mathbf{3 2}$ years, and in excess in i 8 years; but the amounts in excess are much larger than the amounts in defect. The driest summer was 6.80 inches in 1870 , and this was followed by 7.39 inches during the summer of last year, while the wettest summer was 22.03 inches in 1879 .

The sunshine, it will be seen, was very largely deficient; and this was the principal feature of the period, the sun being screened by cloud far more than usual throughout the summer. The smaller amount of sunshine at Greenwich in comparison with Westminster is very pronounced.

The following table gives various elements in connection with the weather for the several districts of the United Kingdom, the results being for the six months, A pril to September, or a period of 26 weeks.

\begin{tabular}{|c|c|c|c|c|c|}
\hline & $\begin{array}{c}\text { Cold } \\
\text { weeks. }\end{array}$ & $\begin{array}{c}\text { Wet } \\
\text { wetks. }\end{array}$ & $\begin{array}{l}\text { Rainy } \\
\text { days. }\end{array}$ & $\begin{array}{c}\text { Total } \\
\text { rainfall. }\end{array}$ & $\begin{array}{l}\text { Hours of } \\
\text { sunshine. }\end{array}$ \\
\hline Scotland, N. & 10 & II & 100 & $\begin{array}{l}\text { ins. } \\
16.8\end{array}$ & 829 \\
\hline Scotland, E. $\quad \ldots$ & I2 & I I & 97 & $15 \cdot 8$ & $8_{42}$ \\
\hline England, N.E. ... & II & 11 & 103 & $13 * 3$ & 856 \\
\hline England, E. & 13 & 15 & 102 & 149 & 923 \\
\hline Midland Counties & 14 & II & 89 & 12.5 & 860 \\
\hline England, S. $\quad \ldots$ & I 3 & 14 & 95 & $15^{\circ} \mathrm{O}$ & 1003 \\
\hline Scotland, V. & 16 & II & 93 & 15.9 & 946 \\
\hline England, N.IV.... & 15 & 13 & 99 & $15^{\circ} 0$ & 847 \\
\hline England, S. IV. ... & I3 & II & 103 & $18 \cdot 2$ & 1037 \\
\hline Ireland, N.... ... & 15 & 13 & 110 & I $5^{\circ} \mathrm{O}$ & $8 \mathrm{I}_{4}$ \\
\hline Ireland, $S . . .$. & 14 & 13 & $9^{8}$ & $18 \cdot 6$ & 859 \\
\hline Channel Islands... & II & 15 & 107 & $18 \cdot 6$ & 1131 \\
\hline
\end{tabular}

The frequency of rain is in excess of the average, except in parts of Scotland, and the amount of rain is in excess, except over the northern portion of the kingdom and in the Midland Counties, the total rainfall for the summer in the latter district being two inches short of the average.

The sunshine was generally deficient, although in the north of Scotland there was an excess of nearly 100 hours. The deficiency during the summer amounted to 186 hours in the Channel Islands, 14t hours in the east of England, and IIg hours in the south of England.

Chas. HaRding.

\section{ON MODERN DEVELOPMENTS OF HARVEY'S IVORK.}

THIS annual meeting in memory of Harvey is usually associated with feelings of pleasure and happiness, for it was intended by its immortal founder to commemorate the benefactors of the College and to encourage good fellowship mongst us.

Such commemoration of those who have benefited the College in the past, although it, necessarily, recalls many who have passed away, is, notwithstanding, on ordinary occasions pleasant instead of painful, because the feeling of loss through their death is completely overpowered by the recollection of the good they have done in their lifetime. To.day the case is very different, for the first thought that must needs occur to every one present here is that on this occasion last year our late President showed for the first time what seemed to be imperfect fulfilment of his duty to the College by being late in his attend. ance at the meeting. Perhaps nothing else could have shown more clearly his deep concern for the welfare of the College, and his thorough devotion of every faculty of mind and body to its interests, than the fact that no duty, no pleasure, and no press of occupation could tempt him to leave one iota of his work in the College undone. The only thing that did keep him back was the hand of Death, which, although at the last meeting he and we knew it not, was already laid upon him. Though his death was less happy than that of the great Harvey, inasmuch as he lingered on for days instead of hours after he was first struck down, yet their deaths were alike in this respect that, up to the time of the fatal attack, each was in the full possession of his faculties, each was in the enjoyment of his life. Like Radcliffe and Mead, like Halford and Baillie, and like many other distinguished Fellows of this College, the greatuess of Clark

I The Harveian Oration, delivered at the Royal College of Physicians, on October 13 , by Dr. T. Lauder Brunton, F.R.S.

No. [ 304 , VOL. 50] is to be estimated not by the published works which he has left behind, but by the influence he exerted on his contemporaries. For the very estimation in which his professional skill was held, led to his whole time being taken up in giving advice, and prevented him from having the leisure to work out or record the results of the pathological and clinical observations which both his youthful publications and his later career showed him to be specially fitted to make. I might say very much more about him, but it has already been said much better than I could possibly do it by yourself, Mr. President, in your annual address, and in the eloquent and heart-stirring words which you addressed to the College on the occasion of your taking the presidential chair rendered vacant by the death of Sir Andrew Clark.

But while we are saddened to day by the death of our late President, we hope to be claddened by the presence amongst us again of one whom we all reverence not only as a former President of this College, but as one of the greatest leaders of clinical medicine in this century, Sir IVilliam Jenner. Like IIarvey, Sir IVilliam Jenner is honoured by his College, by his country, by his Sovereign, and by the world at large. In times of trial and danger the lives of the Royal children were committed to the keeping of Harvey by his King ; and to-day the care not only of her own life, but of that of her nearest and dearest, is com. mitted to Sir William Jenner by his Sovereign, in the full and well-grounded assurance that in no other hands could they be more safe. The great clinician, Graves, wished to have as his epitaph "He fed fevers"; but Jenner has advanced much beyond Graves, and, by showing us how to feed the different kinds of fevers, has saved thousands of valuable lives. To-day this College is acknowledging his right to rank with Sydenhan, Ieberden, Bright, and Garrod, by bestowing upon him the Moxon medal for clinical research. In numbering Sir WVilliam amongst its medallists, the College honours itself as well as him, and in acknowledging the great services he has rendered, it is, on this occasion, acting as the mouthpiece of the medical profession, not only in this country, but in the world at large.

It was with the wish to keep green the memory of the benefactors of the College that this oration was instituted by Harvey, and not at all with the intention that it should be devoted to his own praise. But Harvey stands out so high above all others, that it is only natural that in the numerous orations which have been ytarly given before the College of Physicians, the subject-matter should have been, to a great ex. tent, confined to a consideration of Harvey and his works. On looking over many of these orations, I find that everything I could say about Harvey, his person, his circumstances, his character, and his worke, has already been said so fully and eloquently that I could not add to it anything further, nor could I hope to express it even so well. I purpose, therefore, to con. sider to-day some of the modern developments of Harvey's work, more especially in relation to the treatment of diseases of the heart and circulation. There is, I think, a certain advantage in this also, inasmuch as one is apt by considering Harvey's work only as he left it, to overlook the enormous extent to which it now influences our thoughts and actions; and thus to comprehend its value very imperfectly.

As he himself says, "From a small seed springs a mighty tree; from the minute gemmule or apex of the acorn, how wide does the gnarled oak at length extend his arms, how loftily does he lift his branches to the sky, how deeply do his roots strike down into the ground!" 1

How very minute is the gemmule from which has sprung everything that is definite in medical science, for this gemmule is no other than the idea which Harvey records in these simple words: "I began to think whether there might not be motion as it were in a circle."

Out of this idea has grown all our knowledge of the processes of human life in health and disease, of the signs and symptoms which indicate disease, of the mode of action of the drugs and appliances which we use, and the proper means of employing them in the cure of disease. In the works that have come down to us, we find that IIarvey developed his idea physiologically in several directions. Ile discussed its application to the absorption and distribution of nourishment through the body, the mixing of blood from various parts, the maintenance and distribution of animal heat, and excretion through the kidneys. How far he developed it in the direction of pathology and therapeutics we do not know, as the results of his labours

1 "The Works of W. Harvey," Sydentam Society's Edition, p. 320. 